\title{
OKRES BUDŻETOWY W UJĘCIU POZNAŃSKIEJ SZKOŁY SKARBOWOŚCI
}

Powstały 7 maja 1919 r. Uniwersytet Poznański, zwany początkowo Wszechnica Piastowska, nawiązywał do tradycji istniejących od XVI w. szkół akademickich miasta Poznania. Były nimi ufundowana przez biskupa poznańskiego Jana Lubrańskiego w 1519 r. Akademia Lubrańskiego, jako filia Uniwersytetu Jagiellońskiego, a następnie powołany przywilejem fundacyjnym króla Zygmunta III Wazy w 1611 r. (potwierdzonym przez przywileje następnych polskich królów - Jana Kazimierza w 1650 r. i Jana III Sobieskiego w 1678 r.) samodzielny uniwersytet na bazie istniejącego wcześniej kolegium jezuickiego, dla kształcenia przede wszystkim młodzieży z Wielkopolski i Prus Królewskich ${ }^{1}$. Reaktywowany po odzyskaniu przez Polskę niepodległości po 150 latach zaborów Uniwersytet Poznański był w latach 1919-1939 jedynym polskim uniwersytetem na zachód od Wisły.

Twórca poznańskiej szkoły skarbowości i prawa skarbowego w 1919 r. (obecnie finansów publicznych i prawa finansowego) na Wydziale Prawno-Ekonomicznym Uniwersytetu Poznańskiego był profesor Edward Taylor, wychowanek Wydziału Prawa Uniwersytetu Jagiellońskiego ${ }^{2}$. Był mentorem naukowym oraz autorytetem moralnym dla tysięcy polskich prawników i ekonomistów. Wielu jego byłych studentów było następnie założycielami katedr finansowych na wielu polskich uczelniach, między innymi Poznania, Łodzi, Krakowa, Warszawy, Szczecina czy Sopotu. Powszechnie znana była opinia, że komunizm w Polsce miał bardziej ludzkie oblicze niż w innych krajach bloku wschodniego tylko dlatego, iż szereg kluczowych funkcji w ówczesnym aparacie władzy państwowej pełnili liberalnie ukształtowani uczniowie E. Taylora. I to właśnie z powodów politycznych władze komunistyczne pozbawiły prof. E. Taylora w 1949 r. katedr na poznańskich uczelniach i przeniosły go w stan spoczynku.

Wskutek ustaleń mocarstw w Jałcie i włączenia Polski po II wojnie światowej do strefy wyłącznych wpływów ZSRR nastąpiły zasadnicze zmiany w dotychczasowych rynkowych regulacjach prawnofinansowych, przeszczepienie obcych dotychczasowej kulturze prawnej wzorów ustawodawstwa radzieckiego. W ideologii komunizmu kategorie pieniężne były marginalizowane,

\footnotetext{
${ }^{1}$ Por. szerzej Z. Boras, Tradycje uniwersyteckie Poznania, Poznań 2003.

${ }^{2}$ Por. szerzej J. Małecki, Poznańska szkoła skarbowości w okresie dwudziestolecia międzywojennego, w: Finanse, banki i ubezpieczenia $w$ Polsce u progu XXI wieku, t. 1: Finanse publiczne, Poznań 2000, s. 62-69; E. Borkowska-Bagieńska, Edward Taylor czy wartości niedoceniane?, Poznań 2004.
} 
co oznaczało również pomniejszanie znaczenia regulacji prawnofinansowych, a ponadto stawały się one w szeregu przypadków narzędziem walki politycznej, eliminowania metodami administracyjnymi z prowadzenia działalności gospodarczej podmiotów niepaństwowych. Odchodzono przy tym w tych regulacjach prawnych między innymi od takich fundamentalnych zasad gospodarki rynkowej, jak: równość wobec prawa, powszechność opodatkowania, jawność finansów publicznych, istotne władztwo parlamentu w sferze finansów publicznych i decydująca rola ustaw w regulowaniu stosunków prawnofinansowych, stabilność regulacji prawnych i dostępność przepisów prawnych w dziennikach urzędowych.

Powyższe zmiany polityczne po II wojnie światowej w Polsce spowodowały, że nie wszyscy polscy profesorowie uniwersyteccy finansów publicznych i prawa finansowego chcieli być apologetami nowej władzy komunistycznej. Oznaczało to dla nich konieczność odejścia z uniwersytetu albo zajęcia się taką domena nauki, w której działania cenzury oraz różnych struktur partyjnych i organów bezpieczeństwa stosunkowo najmniej ograniczały wolny umysł naukowca i możliwość swobodnego wypowiadania się. Dlatego Katedra Prawa Finansowego Uniwersytetu Poznańskiego kierowana przez ucznia prof. E. Taylora i jego następcę - prof. Jana Zdzitowieckiego, a następnie prof. Andrzeja Komara aż do początku lat 90. XX w., skoncentrowała swą aktywność naukową na problematyce prawa budżetowego, będąc $\mathrm{w}$ tym zakresie czołowym ośrodkiem naukowym w Polsce. Na Uniwersytecie Poznańskim w tym okresie i z tej problematyki zakończono 9 habilitacji (F. Holeczek, J. Zajda, A. Komar, W. Łączkowski, J. Szpunar, E. Wojciechowski, E. Tegler, J. Małecki, E. Sosnowski) oraz obroniono ponad 40 doktoratów, a godność doktora honoris causa nadano prof. W. Trąmpczyńskiemu i prof. S. Rozmarynowi. Niektóre $\mathrm{z}$ powstałych $\mathrm{w}$ Poznaniu prac naukowych $\mathrm{z}$ natury więc rzeczy dotyczyć musiały tak istotnego dla finansów państwa problemu, jakim jest perspektywa czasowa okresu budżetowego. Ograniczone ramy niniejszego opracowania pozwalają jedynie na wskazanie niektórych poznańskich pionierskich opracowań i tez w nich zawartych dotyczących form prawnych oraz okresu planowania finansowego.

Przez ponad 20 lat prof. J. Zdzitowiecki ${ }^{3}$ na łamach prestiżowych wówczas czasopism naukowych (m.in. „Ruchu Prawniczego, Ekonomicznego i Socjologicznego” oraz „Państwa i Prawa”) kontynuował przedwojenne dzieło prof. T. Grodyńskiego, publikując cykl artykułów poświęconych prawnoporównaczym aspektom gospodarki budżetowej ${ }^{4}$. Powstała na ich postawie wspaniała

${ }^{3} \mathrm{O}$ sylwetce prof. J. Zdzitowieckiego pisze szerzej m.in. E. Wojciechowski w: A. Kostecki (red.), $Z$ dziejów katedr skarbowości $i$ prawa skarbowego oraz katedr prawa finansowego, Kraków 2010, s. $137-142$.

${ }^{4} \mathrm{Sa}$ to m.in. następujące artykuły dotyczące problematyki okresu budżetowego: Nowa treść niektórych zasad budżetowych, „Państwo i Prawo” 1953, z. 2; Ustawa budżetowa, „Ruch Prawniczy, Ekonomiczny i Socjologiczny” 1959, z. 3; Rok budżetowy, „Ruch Prawniczy, Ekonomiczny i Socjologiczny” 1961, z. 3; O dochodach $i$ wydatkach budżetu państwa w Konstytucji PRL, „Ruch Prawniczy, Ekonomiczny i Socjologiczny” 1963, z. 1; O przedtużeniu okresu budżetowego, „Ruch Prawniczy, Ekonomiczny i Socjologiczny 1966”, z. 1; Budżet państwa, budżet centralny i budżety terenowe w Konstytucji PRL, „Ruch Prawniczy, Ekonomiczny i Socjologiczny” 1966, z. 4; Zasady budżetowe, budżet i plan gospodarczy na tle Konstytucji Polskiej Rzeczypospolitej Ludowej, „,Ruch Prawniczy, Ekonomiczny i Socjologiczny” 1969 , z. 3. 
monografia Budżet $w$ Konstytucji PRL, która została jednak odrzucona na początku lat 70. XX w. $\mathrm{z}$ uzasadnieniem cenzorów, że preferuje wzorce obowiązujące $\mathrm{w}$ gospodarce kapitalistycznej i jest zatem nieprzydatna dla państwa socjalistycznego.

Już przed 50 laty prof. J. Zdzitowiecki w swych pracach naukowych (opartych na imponującej jak na owe czasy zniewolenia komunistycznego bibliografii obcej) opowiedział się za celowością rozważenia i wprowadzenia w Polsce wieloletniego planowania budżetowego, powiązania instytucji budżetu $\mathrm{z}$ wieloletnimi planami gospodarczymi. Wskazywał na to, że dla stosowania jednorocznego okresu obowiązywania budżetu przytaczano w przeszłości różne uzasadnienia, na przykład: dostosowania rytmu finansów państwa do gospodarstwa o przewadze rolnictwa i poddanego słonecznemu ,cyklowi” czterech pór roku; odwołania się do koncepcji „dobrego ojca rodziny”; dostosowania finansów publicznych do zwyczajów obowiązujących w gospodarce prywatnej, $\mathrm{w}$ jej stosunkach handlowych i prawnych; względy z zakresu techniki budżetowej w zakresie realnego planowania dochodów i wydatków państwa; względy polityczne mające na celu zapewnienie parlamentowi możność częstego wglądu w gospodarkę finansową rządu i udzielania władzy wykonawczej wiążących wskazówek.

Rozwój jednak w XX w. nowych stosunków gospodarczych i społecznych sprawił, że klasyczna zasada roczności budżetu została w ten czy inny sposób zakwestionowana lub podważona. I to zarówno w ustrojach kapitalistycznych, jak i socjalistycznych, aczkolwiek tu i tam - z innych przyczyn, w inny sposób i w różnych celach. Wątpliwości co do celowości i użyteczności zachowania klasycznej zasady roczności budżetu pojawiły się w krajach kapitalistycznych - najpierw w Skandynawii - ze względu na kłopoty z utrzymaniem $\mathrm{w}$ tak stosunkowo krótkim okresie równowagi budżetowej w czasach koniunkturalnych depresji gospodarczej. Trudności te pogłębiały się następnie ze względu na zwiększanie się bezpośredniego udziału państwa w życiu gospodarczym, zajmowanie się przez państwo nie tylko zaspokajaniem potrzeb ludzkich. Nowa polityka - zapewne pod wpływem poglądów Johna M. Keynesa wysunęła postulat budżetu manipulowanego, będącego narzędziem kompensacji między tłustymi i chudymi laty cyklu koniunkturalnego, zapewnienia równowagi gospodarczej w ciągu jakiegoś dłuższego niż jeden rok okresu.

Zdaniem J. Zdzitowieckiego i w państwach socjalistycznych przemiany, jakie zaszły w ich życiu gospodarczym i metodach kierowania gospodarka, sprawiły, że jednoroczny okres budżetowy stał się niedogodny. Ze względu na obowiązujące powiązanie budżetu $\mathrm{z}$ wieloletnim planem gospodarczym sugerował zatem przyjęcie dla budżetu takiego samego okresu jak dla planu gospodarczego. Taki jednak wieloletni budżet nie mógłby być tak szczegółowy jak budżet roczny. Ten utrzymany w ogólniejszych sumach budżet wieloletni byłby wykonywany przez rząd w sposób ciaggy - z roku na rok. By zachować polityczne i kontrolne uprawnienia parlamentu w sprawach finansowych państwa, uważał, iż nie ma przeszkód, by rząd ponadto sporządzał na każdy rok szczegółowy i opublikowany układ wykonawczy budżetu, a jego wykonanie było przedmiotem corocznej kontroli parlamentu, połączonej z udzieleniem rządowi absolutorium. 
Jednocześnie taki coroczny akt ustosunkowania się izby ustawodawczej do działalności finansowej rządu nie powinien wykluczać ogólniejszej oceny stanu finansów państwa po zakończeniu całego paroletniego okresu budżetowego.

Jedynym z najbardziej oryginalnych ze względu na twórczość naukową, wszechstronnie przygotowanym do pracy naukowej przedstawicieli poznańskiej szkoły skarbowości (studia z zakresu prawa i ekonomii na uniwersytetach w Berlinie, Monachium, Lipsku, Fryburgu i Heidelbergu) był prof. Roch Knapowski, związany naukowo z Katedrą Prawa Finansowego Uniwersytetu Poznańskiego w latach 1923-1962 ${ }^{5}$. Habilitował się z prawa finansowego oraz historii starożytnej i był jednym z nielicznych w świecie wybitnych znawców starożytnych finansów publicznych. Szereg jego prac, wobec braku zainteresowania polskich wydawców finansami antycznymi, było przez prof. R. Knapowskiego tłumaczonych i wydawanych za granica (m.in. w Stanach Zjednoczonych, Japonii, w Włoszech i Niemczech). Dzięki tym publikacjom wzbogacona została literatura światowa $\mathrm{z}$ zakresu tak unikatowej problematyki. Był jednym z tych nielicznych przedstawicieli nauki prawa finansowego, którzy genezę i rozwój instytucji budżetu państwa wiązali z rozwiniętymi zapisami i wydatkami publicznymi dokonywanymi już $\mathrm{w}$ starożytności ${ }^{6}$. W szeregu swych prac poświęconych budżetom państw antycznych (np. Rachunki skarbowe imperium rzymskiego za Trajana, t. 1, przyjęta do druku przez Polską Akademię Umiejętności w Krakowie w 1938 r.; O tupach platejskich. Studium skarbowo-historyczne, Poznań 1947; Finanse wojenne Aleksandra Wielkiego, „Kwartalnik Historyczny Instytutu Historii PAN" 1958, nr 115; Der Staatshaushalt der römischen Republik, Frankfurt a.M. 1961, ss. 519; Die Staatsrechnungen der römischen Republik in den Jahren 49-45 v. Chr., Frankfurt a.M. 1967, ss. 282) wskazywał na to, że perspektywa gospodarki finansowej państwa antycznego nie ograniczała się tylko do jednego roku. Realizacja takich czy innych dalekosiężnych planów i w starożytności stwarzała konieczność ich wieloletniego finansowania, zapewnienia stałego dopływu dostatecznych środków z rozległych imperiów starożytności.

Jednym z trzech istotnych nurtów działalności badawczej prof. Andrzeja Komara, kierownika Katedry Prawa Finansowego UAM w latach 1969-1999 r., była problematyka budżetowa. Z natury rzeczy w swych licznych monografiach $^{7}$, artykułach ${ }^{8}$ i podręcznikach akademickich odnosić się musiał do perspektywy czasowej planowania budżetowego, roli, jaką spełniają budżety roczne. Przykładowo zatem można tutaj jedynie wskazać, że jako pierwszy $\mathrm{w}$ polskiej literaturze prawnofinansowej propagował ideę wieloletniego planowania budżetowego, przybliżając i wyjaśniając $\mathrm{w}$ swych nowatorskich

\footnotetext{
${ }^{5}$ Szerzej o prof. R. Knapowskim pisze m.in. A. Komar, w: A. Kostecki (red.), op. cit., s. 134-136.

${ }^{6}$ N. Gajl, Budżet a skarb państwa, Warszawa 1974, s. 53 i n.

${ }^{7}$ Por. np. Struktura budżetu PRL, Warszawa 1966; Finanse rad narodowych, Warszawa 1970; Kierunki usprawnienia funkcjonowania budżetu, w: Przebudowa systemu budżetowego, Warszawa 1974; Finanse gmin, Warszawa 1977; Gospodarka budżetowa Europejskich Wspólnot, Poznań-Warszawa 1981.

${ }^{8}$ Por. np. Budżet i plan finansowy, „Roczniki Ekonomiczne” 20, 1967-1968; Pięcioletni plan badań naukowych z zakresu prawa finansowego, ,Życie Szkoły Wyższej” 1968, nr 6; Tok i metody planowania finansowego, Poznań 1970; Problematyka gospodarki budżetowej Europejskich Wspólnot, „Finanse” 1977, nr 9; Podstawy finansowe Unii Europejskiej, ,,Sprawy Międzynarodowe” 1985, nr 5.
} 
podręcznikach akademickich ${ }^{9}$ stosowane $\mathrm{w}$ praktyce wysoko rozwiniętych państw zachodnich cztery metody planowania budżetowego mające na celu przezwyciężenie wad planowania budżetowego, zorientowanego przede wszystkim na 1 rok budżetowy, na określenie wydatków i układ resortowy. To z podręczników akademickich i wykładów prof. Komara polscy studenci prawa dowiadywali się, na czym polegaja, jakie sa zalety i wady takich metod planowania budżetowego, jak: system planowania, programowania i budżetowania (Planning-Programming-Budgeting-System - PPBS) opracowany w latach 60. XX w. w Stanach Zjednoczonych; metoda analizy kosztów i korzyści (Cost-Benefit-Analysis) przewidziana swego czasu przez prawo budżetowe Republiki Federalnej Niemiec; metoda budżetowania na podstawie zerowej (Zero-Base-Budgeting) stosowana w praktyce Stanów Zjednoczonych od połowy lat 70. XX w.; metoda tak zwanego ustawodawstwa zachodzącego słońca (Sunset-Legislation).

Andrzej Komar wskazywał jednocześnie na to, jak ważnym zagadnieniem z zakresu opracowania projektu budżetu stanowi określenie relacji planowania rocznego do wieloletniego. Budżet bowiem jako narzędzie alokacji, podziału i stabilizacji powinien nawiązywać do prognozowanego kształtowania się cyklu koniunkturalnego. Cykl koniunkturalny ma przebieg wieloletni i tym samym planowanie budżetowe powinno być ujęte w okresach wieloletnich. Oczywiście może ono być stosunkowo ogólne, ale powinna w nim być ujęta polityka państwa na okresy wieloletnie. Jest to ważne ze względu na cykl wyborów parlamentarnych i układy koalicyjne rządu. Cykle polityczne wstrząsają bowiem pracami nad projektem budżetu, a partie polityczne kieruja się interesami doraźnymi. Uregulowanie założeń planowania wieloletniego w konstytucji i w prawie budżetowym mogłoby te wahania ograniczyć.

Zdaniem A. Komara równie istotną sprawą jest uregulowanie stosunku planowania rocznego do wieloletniego. Chodzi w nim o określenie, w jakim stopniu wydatki ujęte w projektach wieloletnich powinny być uwzględnione w projekcie ustawy budżetowej na dany rok. Nie jest to jednak łatwe do uregulowania prawnego, gdyż od $70 \%$ do $85 \%$ pozycji budżetowych to kontynuacja $\mathrm{z}$ lat poprzednich. W rezultacie zadania nowe maja małe szanse ujęcia w projekcie budżetu rocznego. Niemniej prognozy w zakresie wieloletniego kształtowania się dochodów i wydatków powinny stanowić punkt wyjścia rocznego planowania budżetowego. Autor postulował posłużenie się $\mathrm{w}$ tym zakresie metodą zerowej podstawy budżetowania: zadania kontynuowane i nowe powinny mieć takie same szanse włączenia do budżetu. W praktyce jednak minister finansów byłby związany uprzednimi zobowiązaniami wynikającymi z przepisów prawa lub z umów.

Problematyka perspektywy finansowej eksponowana była także w pracach prof. Wojciecha Łączkowskiego ${ }^{10}$. Nowy system planowania, programowania i budżetowania wprowadzony przez administrację Stanów Zjednoczonych,

\footnotetext{
${ }^{9}$ Por. np. A. Komar, Finanse publiczne, Warszawa 1994, s. 76-86; idem, Finanse publiczne $w$ gospodarce rynkowej, Bydgoszcz 1996, s. 91-101.

${ }^{10}$ Por. np. tegoż autora: Kompetencje organów państwa w zakresie autoryzacji budżetu, Poznań 1968; Polityka finansowa PRL (1966-1970), Poznań 1970; Polityka finansowa PRL (1971-1975), Poznań 1974; Budzetowe $i$ kredytowe metody ksztattowania decyzji, Warszawa 1978.
} 
a w różnych wariantach przejmowany przez szereg innych wysoko rozwiniętych państw kapitalistycznych, został przybliżony polskiemu czytelnikowi już w 1971 r. ${ }^{11}$ Zdaniem autora, mimo istniejących wówczas różnic ustrojowych w Polsce i w wysoko rozwiniętych krajach kapitalistycznych nowe metody planowania budżetowego i zwiększone czasowo perspektywy tego planowania mogły być inspirujące dla podejmowanych ówcześnie krajowych reform zarządzania i doskonalenia finansów publicznych. W rzeczywistości PPBS jest bowiem dyscypliną praktyczna, która ma jedynie ułatwić lepszy, racjonalniejszy wybór najwłaściwszej decyzji i dać możliwie najprawdziwsze, obiektywne informacje; jest systemem złożonym, niejednolitym, wymagającym szczegółowej adaptacji $\mathrm{w}$ poszczególnych państwach. W krajach europejskich jest ciagle jeszcze przedmiotem eksperymentów i dlatego nie można nawet dać jednoznacznej definicji tego systemu. Co najwyżej można mówić o coraz wyraźniej zarysowujacych się jego cechach. Jedno tylko przy tym nie jest wątpliwesystem PPB powinien być integralnie związany z polityka państwa, przez nia określony i równocześnie przyczyniać się do podejmowania optymalnych decyzji, w przeciwnym razie planowanie i programowanie może stać się celem samym $\mathrm{w}$ sobie, przekształcając się $\mathrm{w}$ najlepszym razie $\mathrm{w}$ pusty rytuał albo - co gorsza - może nawet ograniczać zdolność prowadzenia jednolitej i konsekwentnej polityki budżetowej. Z tego punktu widzenia szczególnie groźne jest zmniejszanie się wiary w zdolności ludzkiej inteligencji, wykształcenie się wraz z systemem PPB swoistego typu mistycyzmu pozwalającego za pomoca wymyślnych, sofistycznych metod usprawiedliwiać społecznie szkodliwe decyzje ich ,efektywnością”. Już przed laty W. Łączkowski podkreślał, że system PPBS odegra postępową role tylko wówczas, gdy będzie rozpatrywany na szerszym tle ogólnych wysiłków zmierzających do usprawnienia polityki społeczno-gospodarczej. Systemu tego nie powinno się zatem traktować jako jedynego czynnika wpływającego na decyzje w dziedzinie polityki społeczno-gospodarczej, chociaż jest to czynnik bardzo ważny. Ten jednak punkt widzenia jest najczęściej pomijany zarówno w literaturze na temat PPBS, jak i w praktyce wprowadzania tego systemu do administracji publicznej.

Przeprowadzana w Polsce w latach 1972-1973 reforma ustrojowa rad narodowych zrodziła również konieczność przeprowadzenia reformy finansów lokalnych. W literaturze prawnofinansowej tamtego okresu podkreślano bowiem, że podstawowe źródło finansowania zadań lokalnych - budżety rad narodowych nie odgrywały aktywnej roli w zarządzaniu gospodarką terenowa. Przyczyn tego stanu rzeczy upatrywano między innymi w nadmiernej centralizacji systemu budżetów lokalnych, braku stabilizacji zasad i podstaw tego systemu. Uchwałą ówcześnie rządzącej partii komunistycznej zapowiedziano zatem zmiany $\mathrm{w}$ dotychczasowym systemie budżetowym polegające między innymi na wprowadzeniu wieloletniego planowania budżetowego, 5-letnim bilansowaniu dochodów i wydatków rad narodowych, a także zwiększeniu własnych dochodów budżetów terenowych.

${ }^{11}$ W. Łączkowski, Planowanie, programowanie $i$ budżetowanie $w$ rozwiniętych gospodarczo państwach kapitalistycznych, „Państwo i Prawo” 1971, z. 12, s. 999-1004. 
Zapowiadana przez czynniki polityczne owa reforma budżetów lokalnych została poprzedzona eksperymentem, mającym na celu uzyskanie niezbędnych doświadczeń w zakresie wieloletniego planowania budżetowego. Realizację owego eksperymentu z planowaniem wieloletnim ${ }^{12}$, przeprowadzanym w latach 1974-1975, zlecono województwu poznańskiemu, szczecińskiemu, wrocławskiemu i miastu Wrocław. Eksperyment dwuletniego planowania w województwie poznańskim wdrażano i nadzorowano z aktywnym udziałem 2 ówczesnych doktorów Katedry Prawa Finansowego UAM ${ }^{13}$. Ten pierwszy w Polsce eksperyment $\mathrm{z}$ dwuletnim planowaniem budżetowym oparty był na następujących zasadach:

- podstawę planowania dochodów i wydatków budżetowych na lata 1974-1975 stanowić miały wycinki pięcioletniego planu społeczno-gospodarczego województwa;

- zasady i tryb opracowania budżetów terenowych na okres dwuletni oparto na takich samych podstawach jak planowanie roczne, z tym że dla $1975 \mathrm{r}$. miano jedynie rozpatrywać zmiany wynikające $\mathrm{z}$ przejęcia lub przekazania zadań z tytułu zmiany cen, marż, taryf, stawek płac i norm budżetowych oraz innych decyzji władz centralnych rzutujących na ustalone dochody i wydatki;

- zamiast dotychczasowych udziałów w dochodach budżetu centralnego i dotacji wyrównawczej eksperymentującym województwom przyznano dwa nowe źródła dochodów, a mianowicie wpływy z tytułu obciążenia funduszu płac państwowych przedsiębiorstw produkcyjnych (dla woj. poznańskiego udział ten wynosił $14,2 \%$ rocznego funduszu płac) i wpływy w wysokości $1 \%$ wartości sprzedaży handlu uspołecznionego;

- w przypadku przekroczenia planowanych dochodów z tytułu obciążenia funduszu płac, obrotu detalicznego, podatku od wynagrodzeń i funduszu płac o 3\%, nadwyżka podlegała przekazaniu na odpowiedni fundusz zasobowy rady, z którego możliwe było dodatkowe finansowanie przedsięwzięć mającą na celu aktywizację gospodarki terenowej;

- rozszerzono również dla eksperymentujących województw zakres dotacji celowych, którymi obok wydatków inwestycyjnych objęto także wydatki na leki dla uprawnionych i dotacje dla państwowych gospodarstw rolnych.

$\mathrm{W}$ ocenach tego pierwszego w Polsce eksperymentu $\mathrm{z}$ wieloletnim planowaniem budżetowym z lat 1974-1975 między innymi wskazano na to, że w trakcie realizacji eksperymentu dokonane zostały istotne zmiany $\mathrm{w}$ stosunku do początkowych założeń. Koniecznym zaś warunkiem realizacji idei budżetów wieloletnich jest między innymi stabilizacja systemu finansowego, cen, marż, stóp kredytowych czy konstrukcji podatkowych oraz synchronizacji planowania gospodarczego z planowaniem budżetowym.

${ }^{12}$ Por. kolejne ustawy budżetowe: na rok 1973 (Dz. U. Nr 52, poz. 337); na rok 1974 (Dz. U. Nr 50, poz. 286) i na rok 1975 (Dz. U. Nr 48, poz. 293), a także $§ 1$ ust. 2 zarządzenia nr 62 Ministra Finansów z 7 czerwca 1973 r. w sprawie opracowania projektów budżetów terenowych na rok 1974 (niepubl.) i $\$ 1$ ust. 2 zarządzenia nr 63 Ministra Finansów z 15 czerwca 1974 r. w sprawie opracowania projektów budżetów terenowych na 1975 r. (niepubl.).

${ }^{13}$ Por. J. Małecki, M. Małecki, Pierwsze wnioski z eksperymentu budżetowego, „Rada Narodowa, Gospodarka, Administracja” 1975, nr 11, s. 27-28. 
Niestabilność owych czynników makroekonomicznych w gospodarce polskiej spowodowała, że na wiele lat zostały odłożone wszelkie próby wprowadzenia do polskiego systemu finansowego idei planowania wieloletniego.

prof. dr hab. Jerzy Matecki

Uniwersytet im. Adama Mickiewicza w Poznaniu

\section{A BUDGET PERIOD IN THE APPROACH OF POZNAŃ SCHOOL OF PUBLIC FINANCE}

\section{Summary}

Poznań School of Public Finance was created in 1919 by professor Edward Taylor, a member of the Law and Economy Faculty of the Poznań University, and a mentor and moral role model for thousands of Polish lawyers and economists that followed. For political reasons, for fifty years after World War II, the research work of the Department of Financial Law of the University's Law and Economy Faculty concentrated on budget laws. In that period Poznań became a leading research centre specialising in state and local finance in Poland. The paper presents selected dissertations of the researchers from the Department of Financial Law, devoted to the pioneering aspects of the budget period and long-term financial planning. 